\title{
Anti-HIV-1 seroreactivity and HIV transmission route[R1]
}

\author{
V. Bongertz ${ }^{\text {a,*}}$, M.L. Guimarães a, M.F.G. Soares-da-Costa a, V.G. Veloso a, \\ F.I. Bastos ${ }^{b}$, C.L. Szwarcwald ${ }^{\text {b }}$, M. Derrico ${ }^{\text {b }}$, P.R. Telles ${ }^{\text {c }}$, J.H. Pilloto ${ }^{\text {, }}$, \\ E.C. João Filho ${ }^{\mathrm{e}}$, M.G. Morgado ${ }^{a}$, The HEC/FIOCRUZ AIDS Clinical Research \\ Group $^{\mathrm{a}}$ \\ a Laboratório de AIDS e Imunologia Molecular e Hospital Evandro Chagas, Instituto Oswaldo Cruz, Fiocruz, Av Brasil 4365, \\ 21045-900, Rio de Janeiro, Brazil \\ ${ }^{\mathrm{b}}$ Centro de Informações em Ciência e Tecnologia, Fiocruz, Av Brasil 4365, 21045-900, Rio de Janeiro, Brazil \\ ' NEPAD, Universidade Estadual do Rio de Janeiro, Rio de Janeiro, RJ, Brazil \\ ' Hospital Geral de Nova Iguaçu, Rio de Janeiro, RJ, Brazil \\ e Hospital dos Servidores do Estado, Rio de Janeiro, RJ, Brazil
}

Received 17 September 1998; received in revised form 28 October 1998; accepted 28 October 1998

\begin{abstract}
Background: antibody binding assays carried out by our group have consistently indicated a higher reactivity of sera from male HIV-1 infected individuals. This study was carried out in order to analyze the importance of gender, route of transmission, disease progression and HIV-1 genotype in seroreactivity assays.

Study design: specificity of antibody binding was studied in plasma of 247 HIV-1 seropositive individuals belonging to patient groups of pregnant women, injecting drug users (IDUs) and recent seroconvertors, resident in Rio de Janeiro, RJ. Recognition of synthetic peptides corresponding to antigenically important epitopes in the envelope of HIV-1 (gp41 immunodominant epitope, V3 loop, V2 loop and gp41 735-752 epitope) was determined.

Results: the immunodominant gp41 peptide (amino acids 594-613, HIV-1 MN sequence) was recognized by $85 \%$ of all plasma tested. Reactivity with the gp41 735-752 peptide and gp120 V2 loop peptides was low but quite variable, being generally more often specific to a Brazilian V2 peptide used than to the HIV-1 MN derived V2 peptide. The overall recognition of the different V3 peptides tested varied from 41 to $76 \%$. Patients with more advanced disease showed a more frequent reactivity with the peptides studied than did asymptomatic patients. Statistically significant differences in peptide recognition were observed by multiple logistic analyses comparing plasma derived from individuals infected by blood or sexual HIV transmission, adjusting for disease progression and gender. Plasma from individuals infected by sexual transmission showed lower peptide recognition than did plasma from individuals infected through HIV positive blood. Association attempts between seroreactivity and genotype indicated that plasma derived from patients infected with HIV-1 of the F subtype showed highest recognition of
\end{abstract}

* Corresponding author. Fax: + 55-21-2801589; e-mail: bongertz@gene.dbbm.fiocruz.br. 
heterologous V3 peptides, as well as a slightly more frequent recognition of the non-V3 peptides tested. Recognition of homologous peptides was generally higher than recognition of heterologous peptides. Differences were most pronounced between the prototypical HIV-1 B subtype and the Brazilian B" variant of this subtype but almost non-existent between the HIV-1 B and F subtypes.

Conclusions: individual gender was shown to be a confounder when investigating the relationships of peptide reaction to HIV-1 route of transmission through multivariate statistical methods: patients infected by blood transmission (IDU) present higher frequency of peptide recognition than individuals infected by sexual HIV-1 transmission. Plasma from individuals infected with the $\mathrm{B}^{\prime \prime}$ variant (GWG) of B subtype HIV-1 showed lower heterologous peptide recognition than that from HIV-1 B (GPG) or F infected individuals. (C) 1999 Elsevier Science B.V. All rights reserved.

Keywords: HIV; Seroreactivity; Transmission; Genotypes

\section{Introduction}

The striking HIV-1 variability is known to be an important issue in the global AIDS epidemic, creating difficulties for the development of a broadly effective AIDS vaccine. Different HIV-1 subtypes cluster in different geographic areas (Expert Group of the Joint United Nations Programme on HIV/AIDS, 1997), although with time these geographical definitions seem to get 'blurred'. Also, the emergence of 'escape mutants' with disease progression has been described in several studies of molecular (Schreiber et al., 1994) and immunological (Watkins et al., 1993) HIV-1 characterization. In Brazil, a series of studies have identified the HIV-1 subtype B as the major viral type, although every study identified at least one other HIV-1 subtype in the same geographical area (Potts et al., 1993; Morgado et al., 1994; WHO Network for HIV Isolation and Characterisation, 1994; Galvão-Castro et al., 1996). The data obtained up to now describe HIV-1 subtypes B, F and C in Brazil, with cases of recombinant HIV-1 (Sabino et al., 1994; Gao et al., 1996), as well as isolated cases of subtype D (Morgado et al., 1998).

Up to now, reactivity of HIV-1 sera with gp120 V3 loop peptides has been used in attempts to serotype HIV-1 infection in substitution to the more expensive and labor-intensive genotyping using the heteroduplex mobility assay (HMA). However, results have indicated that the use of seroreactivity data for typing HIV-1 is not indicated when molecular subtypes are to be iden- tified. Serotyping of HIV-1 genotypes circulating in Brazil has been attempted with partial result: although distinction of the classical B (GPG) from the $\mathrm{B}^{\prime \prime}$ variant (GWG) has been possible in the majority of cases (Cheingsong Popov et al., 1994; Pau et al., 1994; Hendry et al., 1996; Bongertz et al., 1998a), distinction of B and F HIV-1 subtypes has not been conclusive by any serological method attempted up to now (Casseb et al., 1997; Hendry et al., 1997; Bongertz et al., 1998a). In this study, humoral anti-HIV-1 responses were evaluated using synthetic peptides corresponding to epitopes known to induce HIV-1 neutralizing antibodies and therefore possibly of importance for control of disease progression.

\section{Material and methods}

\subsection{Patients}

A total of 247 voluntary patients, belonging to three different HIV-1 seropositive groups, accompanied by three reference Hospitals, have been involved in this study: (1) Vertical HIV Transmission group, comprised of $97 \mathrm{HIV}-1$ infected pregnant women and women that had given birth recently (including six women infected by injected drug use); (2) 42 individuals from an injecting drug user (IDU) cross-sectional study, comprised of a mostly male group (97\%), part of the multicenter study 'Projeto Brasil' (Brazilian Ministry of Health); and (3) 108 HIV-1 infected individuals resident in Rio de Janeiro, with first positive 
anti-HIV-1 serology within 3 years from sample collection, belonging to different exposure categories. Clinical data were known for most of the patients, as indicated in Table 1.

\subsection{Seroreactivity}

Several custom made synthetic peptides (Chiron Mimotopes, San Diego, CA, USA) were used: (a) corresponding to the V3 loop of HIV-1 subtypes, B (NTRKSIHIGPGRAFY), Brazilian B" (W = NTRKSIHMGWGRAFY and W5 = NTRKSIHIGWGRAFY), C (KSIRIGPGQTFYAT), D (RQRTHIGPGQALYTT), F (RKSIHLGPQAFYTT) and Brazilian F (FBR $=$ NTRKSIPLGPGRAFY); (b) corresponding to gp120 V2 loops of HIV-1 subtype $\mathrm{B}$ isolate $\mathrm{MN}(\mathrm{V} 2 \mathrm{MN}=$ IRDKMQKEYALLYKL) and a Brazilian $\mathrm{B}^{\prime \prime}$ primary isolate (V2BR $=$ VKDKELLEYALFYNL) and; (c) peptides corresponding to a neutralizing epitope in gp41 (amino acids 735-752, $735=\mathrm{DR}$ PEGIEEEGEKDRDRS) and to the immunodominant epitope in gp41 of the HIV-1 isolate $\mathrm{MN}$ (ID = GFWGCSGKLICTTTVPWNAS). Duplicates of sequentially diluted (1:100 at a first step, followed by dilutions at 1:200...1:51,

Table 1

Clinical data available for the patients involved in this study at blood sample collection

\begin{tabular}{|c|c|c|}
\hline Sex & $\begin{array}{l}\text { Female } \\
\text { Male }\end{array}$ & $\begin{array}{l}141(57 \%) \\
106(43 \%)\end{array}$ \\
\hline Clinical staging ${ }^{\mathrm{a}}$ & $\begin{array}{l}\text { II } \\
\text { III } \\
\text { IV }\end{array}$ & $\begin{array}{r}146(63 \%) \\
50(21 \%) \\
37(16 \%)\end{array}$ \\
\hline \# CD $4 / \mathrm{mm}^{3}$ & $\begin{array}{l}>400 \\
200-400 \\
<200\end{array}$ & $\begin{array}{r}106(54 \%) \\
61(31 \%) \\
29(15 \%)\end{array}$ \\
\hline Exposure category & $\begin{array}{l}\text { Heterosexual } \\
\text { MSM }^{\text {b }} \\
\text { IDU }^{\text {b }} \\
\text { Other }\end{array}$ & $\begin{array}{r}123(56 \%) \\
49(22 \%) \\
45(20 \%) \\
3(1.5 \%)\end{array}$ \\
\hline Therapy & $\begin{array}{l}\text { Yes } \\
\text { No }\end{array}$ & $\begin{array}{r}52(29 \%) \\
129(71 \%)\end{array}$ \\
\hline
\end{tabular}

\footnotetext{
${ }^{\text {a }}$ Clinical staging according to Centers for Disease Control (1986).

${ }^{\mathrm{b}}$ MSM, men having sex with other men, IDU, injecting drug users.
}

200 of positive plasma) heat inactivated plasma were incubated $\left(1 \mathrm{~h} / 37^{\circ} \mathrm{C}\right.$ followed by an overnight incubation at $4^{\circ} \mathrm{C}$ ) with different biotinylated synthetic peptides $(5 \mu \mathrm{g} /$ well) bound to multiwell plates (Maxisorb, Nunc, Roskilde, Denmark) precoated with streptavidin $(10 \mu \mathrm{g} /$ well $)$. Specific reactivity was assessed (including two 8 $M$ urea washes after antibody incubation) by peroxidase-conjugated anti-human-IgG binding and peroxide/tetrametilbenzidine revelation. Reactivity was assessed as dilution titer reaching at least twice the mean binding of the two control plasma (obtained from local HIV negative blood donors) included in each assay plate. Absorbency was measured at $450 \mathrm{~nm}$. Background readings at $620 \mathrm{~nm}$ were subtracted. For some of the samples tested in duplicate, reactivity with the peptides was discordant even after repetition, probably indicating low affinity binding partially removed by the $8 \mathrm{M}$ urea washes. These results were considered doubtful and not included in this report, leading to differences in numbers of samples tested with the different synthetic peptides.

\subsection{Heteroduplex mobility assay}

The test was carried out on 145 samples, according to Delwart et al. (1993) using the reagents indicated. Differentiation between B subtype and the B" variant of subtype B was carried out using analysis of Fok 1 restriction enzyme fragments by agarose gel electrophoresis (Morgado et al., 1998).

\subsection{Statistical analyses}

Contingency table analyses $\left(\chi^{2}\right.$ Yates corrected or Fisher's exact test) were used for comparative evaluation of antibody binding to synthetic peptides, comparing plasma from individuals with different disease progression, exposure category and gender. Multivariate analyses were further performed through logistic regression models (stepwise and backward procedures). Data were aggregated in binary categories (sexual versus blood transmission, $<200$ vs. $\geq 200 \mathrm{CD} 4 / \mathrm{mm}^{3}$, male vs. female and clinical staging II plus III vs. IV) to achieve sufficient sample size in cross tabulation. 


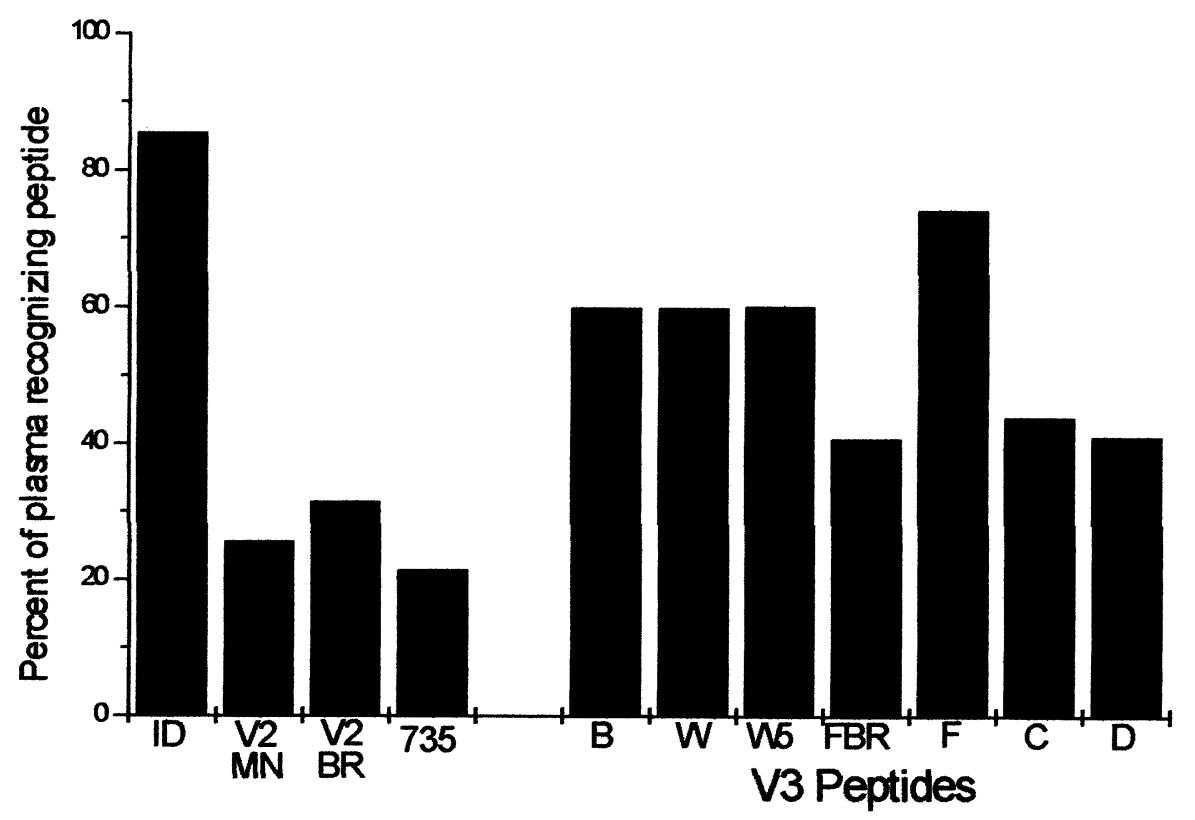

Fig. 1. Recognition of synthetic peptides (immunodominant gp41 peptide (ID), HIV-1 MN V2 loop peptide (V2MN), HIV-1 Br V2 loop peptide (V2BR), gp41 735-752 peptide (735), V3 loop peptides corresponding to HIV-1 subtypes/variants B, B" (peptides W and W5), FBR, F, C and D) by plasma from HIV-1 seropositive individuals $(n=247)$ resident in Rio de Janeiro.

\section{Results}

\subsection{General reactivity}

General reactivity of the plasma with the different peptides used in this study is shown in Fig. 1.

The immunodominant gp41 peptide (amino acids 594-613) was recognized by $85 \%$ of all plasma tested. Reactivity with gp120 V2 loop peptides was low but quite variable, being generally more often specific to the Brazilian V2BR peptide used $(31 \%)$ than to the HIV-1 MN derived V2 peptide $(25 \%)$. Similarly, reactivity with the gp41 735-752 peptide (derived from HIV-1 MN only as it is known to be a quite conserved epitope) was recognized by $22 \%$ of the plasma tested. The overall recognition of the different V3 peptides tested varied from 41 (V3-D, V3-FBR) to $74 \%$ (V3-F), but peptides corresponding to the $\mathrm{B}$ subtype were recognized by $\approx 60 \%$ of the plasma.

\subsection{Peptide recognition and severity of $H I V-1$} disease

Patients with more advanced disease (stages III and IV [Centers for Disease Control, 1986]) showed a higher reactivity with the majority of the peptides studied than did asymptomatic patients (Table 2). This higher reactivity of symptomatic in comparison to asymptomatic patients was significant in recognition of the immunodominant peptide $(P=0.0023)$, the gp41-735 peptide $(P=0.0068)$ and with $\mathrm{V} 3$ peptides derived from Brazilian sequences, peptides W5 $(P=0.0056)$ and FBR $(P=0.0038)$. When AIDS/non-AIDS patients were compared, i.e. clinical stages II + III vs. IV, significantly higher reactivity was similarly observed in AIDS patients $(P=0.001,0.024$, 0.019 and 0.014 , respectively).

When disease progression based on CD4 lymphocyte counts was used, comparing reactivity of patients with less than $200 \mathrm{CD} 4 / \mathrm{mm}^{3}$ to that of 
Table 2

Recognition of synthetic peptides (number of positive plasma/number of plasma tested) by plasma from patients grouped for disease progression, according to clinical staging (Centers for Disease Control, 1986) or number of circulating CD4 lymphocytes at sample collection

\begin{tabular}{lrrlrrl}
\hline & Clinical stage II & Clinical stage III & Clinical stage IV & $\begin{array}{l}>400 \mathrm{CD} 4 / \\
\mathrm{mm}^{3}\end{array}$ & $\begin{array}{l}200-400 \mathrm{CD} / / \\
\mathrm{mm}^{3}\end{array}$ & $\begin{array}{l}<200 \mathrm{CD} / \\
\mathrm{mm}^{3}\end{array}$ \\
\hline ID & $107 / 133(80 \%)$ & $41 / 44(93 \%)$ & $36 / 40(90 \%)$ & $82 / 97(85 \%)$ & $45 / 53(85 \%)$ & $28 / 29(97 \%)$ \\
V2MN & $35 / 138(25 \%)$ & $8 / 41(20 \%)$ & $17 / 39(44 \%)$ & $23 / 99(23 \%)$ & $11 / 58(19 \%)$ & $18 / 29(62 \%)$ \\
V2BR & $44 / 136(32 \%)$ & $13 / 47(28 \%)$ & $16 / 36(44 \%)$ & $28 / 70(40 \%)$ & $16 / 57(28 \%)$ & $14 / 26(54 \%)$ \\
735 & $20 / 137(15 \%)$ & $7 / 49(14 \%)$ & $19 / 38(50 \%)$ & $19 / 85(22 \%)$ & $10 / 56(18 \%)$ & $18 / 29(62 \%)$ \\
B & $81 / 143(57 \%)$ & $29 / 50(58 \%)$ & $31 / 38(82 \%)$ & $55 / 104(53 \%)$ & $39 / 60(65 \%)$ & $25 / 30(83 \%)$ \\
W & $83 / 140(59 \%)$ & $31 / 49(63 \%)$ & $23 / 38(61 \%)$ & $63 / 103(61 \%)$ & $27 / 37(73 \%)$ & $16 / 30(53 \%)$ \\
W5 & $75 / 141(53 \%)$ & $34 / 50(68 \%)$ & $30 / 39(77 \%)$ & $61 / 104(59 \%)$ & $32 / 59(54 \%)$ & $23 / 30(77 \%)$ \\
FBR & $47 / 143(33 \%)$ & $22 / 50(44 \%)$ & $24 / 39(62 \%)$ & $38 / 105(36 \%)$ & $26 / 60(43 \%)$ & $19 / 30(63 \%)$ \\
F & $104 / 142(73 \%)$ & $36 / 50(72 \%)$ & $35 / 40(88 \%)$ & $75 / 105(71 \%)$ & $43 / 59(73 \%)$ & $27 / 30(90 \%)$ \\
C & $56 / 142(39 \%)$ & $21 / 50(42 \%)$ & $23 / 38(61 \%)$ & $40 / 104(39 \%)$ & $24 / 60(40 \%)$ & $16 / 30(53 \%)$ \\
D & $60 / 141(43 \%)$ & $15 / 49(31 \%)$ & $19 / 38(50 \%)$ & $45 / 105(43 \%)$ & $22 / 58(38 \%)$ & $16 / 29(55 \%)$ \\
\hline
\end{tabular}

patients with a higher number of $\mathrm{CD} 4 / \mathrm{mm}^{3}$, no significant difference was observed in reactivity with the immunodominant peptide ID, but significantly higher reactivity of sera from patients with less than 200 CD4 lymphocytes was observed against the peptides gp41-735 $(P=0.000), \mathrm{V} 2 \mathrm{MN}$ $(P=0.000)$, V2BR $(P=0.019)$ and the V3 peptides $\mathrm{B}(P=0.012)$ and FBR $(P=0.012)$.

\subsection{HIV exposure categories}

When results were evaluated independently, statistically significant differences in peptide recognition were observed between plasma derived from different HIV exposure categories (Table 3). Although the sample did not allow analyses of exposure category controlled by gender, plasma from IDU (75.6\% males) showed highest percentile recognition of the peptides tested, most significantly against the V2 derived peptides and the gp41 735-752 peptide. The plasma derived from the men who have sex with men (MSM) exposure category (100\% males) also showed a higher percentile peptide recognition than that recorded for plasma from the heterosexually infected $(93.5 \%$ females) but generally lower than that observed for IDU plasma. Differences in peptide recognition could also be observed between plasma from heterosexually infected individuals and the group of plasma from individuals infected through sexual contacts between men, groups with similar numbers of patients in more advanced stages of infection (statistically significant for peptide V2BR, $P=0.0224$ ). Comparison of reactivities of plasma from symptomatic patients in the different exposure category groups (or individuals with less than 400 CD4 lymphocytes $/ \mathrm{mm}^{3}$ blood) showed very similar results: significantly higher reactivity observed for plasma from symptomatic IDU patients against the V2 peptides, the 735 peptide and the V3 FBR peptide in comparison to reactivity of plasma from symptomatic patients belonging to either the heterosexual or the MSM exposure categories (Table 4).

Multiple logistic analyses were used for each of the peptides that showed significant association with transmission route, disease progression and gender in univariate analyses. For all statistically tested peptides, the route of transmission was the most significant factor, followed by disease progression measured by number of circulating CD4 lymphocytes $(>200$ vs. $<200)$ at sample collection. Blood transmission and $<200 \mathrm{CD} 4 / \mathrm{mm}^{3}$ were always associated to higher peptide recognition. After adjusting for transmission route and disease progression, the effect of gender was not statistically significant for most of the peptides tested (Table 5). The only exception corresponded to V2BR, for which gender showed a borderline significant effect $(95 \% \mathrm{Cl} 1.1-4.6 ; P=0.0261)$. 
Table 3

Recognition of synthetic peptides (number of positive plasma/number of plasma tested) by plasma from individuals grouped according to exposure category or gender of the individual plasma donor ${ }^{\mathrm{a}}$

\begin{tabular}{lrrrrr}
\hline & IDU & \multicolumn{1}{l}{ MSM } & Heterosexual transmission & Male & Female \\
\hline ID & $37 / 42(88.1 \%)$ & $40 / 49(81.6 \%)$ & $93 / 109(85.3 \%)$ & $90 / 104(86.5 \%)$ & $105 / 126(83.3 \%)$ \\
V2MN & $26 / 41(63.4 \%)$ & $11 / 48(22.9 \%)$ & $19 / 119(16.0 \%)$ & $39 / 102(38.2 \%)$ & $22 / 135(16.3 \%)$ \\
V2BR & $22 / 31(67.7 \%)$ & $19 / 49(38.8 \%)$ & $26 / 122(21.3 \%)$ & $4 / 94(46.8 \%)$ & $29 / 109(21.0 \%)$ \\
735 & $24 / 38(63.2 \%)$ & $6 / 49(12.2 \%)$ & $16 / 122(13.1 \%)$ & $25 / 99(25.3 \%)$ & $26 / 139(18.7 \%)$ \\
B & $34 / 45(75.5 \%)$ & $31 / 49(63.3 \%)$ & $67 / 121(55.4 \%)$ & $67 / 106(63.2 \%)$ & $83 / 139(59.7 \%)$ \\
W & $25 / 45(55.6 \%)$ & $30 / 48(62.5 \%)$ & $72 / 119(60.5 \%)$ & $65 / 104(62.5 \%)$ & $79 / 137(57.7 \%)$ \\
W5 & $29 / 44(65.9 \%)$ & $31 / 49(63.3 \%)$ & $73 / 122(59.8 \%)$ & $66 / 103(64.1 \%)$ & $80 / 140(57.1 \%)$ \\
FBR & $32 / 45(71.1 \%)$ & $20 / 49(40.8 \%)$ & $36 / 122(29.5 \%)$ & $51 / 106(48.1 \%)$ & $49 / 139(35.2 \%)$ \\
F & $39 / 43(90.7 \%)$ & $33 / 49(67.3 \%)$ & $87 / 123(70.7 \%)$ & $80 / 104(76.9 \%)$ & $102 / 141(72.3 \%)$ \\
C & $18 / 44(40.9 \%)$ & $20 / 49(40.8 \%)$ & $51 / 120(42.5 \%)$ & $44 / 105(41.9 \%)$ & $63 / 138(45.7 \%)$ \\
D & $27 / 40(67.5 \%)$ & $22 / 49(44.9 \%)$ & $41 / 123(33.3 \%)$ & $49 / 101(48.5 \%)$ & $51 / 141(36.2 \%)$ \\
\hline
\end{tabular}

a IDU, injecting drug users, MSM, men who have sex with men, heterosexual transmission.

\subsection{Peptide recognition by plasma from individuals infected with different HIV-1 genotypes/variants}

For some of the patients involved in this study, HIV-1 genotype/variant identification, using the heteroduplex mobility assay associated to restriction endonuclease digestion, was carried out. Of 145 typed samples, 52\% were identified as B genotype (GPG), 34\% as B" variant of the B genotype (GWG) and 14\% as HIV-1 FBR genotype.

Overall, plasma derived from patients infected with HIV-1 of the F subtype showed highest recognition of heterologous $\mathrm{V} 3$ peptides, as well as a slightly more frequent recognition of the non-V3 peptides tested (Table 6). Less plasma from individuals infected with the $\mathrm{B}^{\prime \prime}$ variant recognized the V2 or gp41/735 peptide, although not statistically significant in relation to $F$ or $B$ plasma. Recognition of the homologous peptide was generally higher than recognition of heterologous peptides. Differences were most significant between the HIV-1 subtype F or the prototypical HIV-1 B subtype and the Brazilian $\mathrm{B}^{\prime \prime}$ variant of this subtype, while almost non-existent between the HIV-1 B and F subtypes. The FBR peptide appears to be more useful for identification of $\mathrm{F}$ plasma as cross-recognition by $\mathrm{B}$ $(P=0.042)$ and $\mathrm{B}^{\prime \prime}$ plasma $(P=0.001)$ is a bit lower than observed for the $\mathrm{F}$ peptide $(P=0.11$ and $P=0.003$, respectively). The $\mathrm{B}^{\prime \prime}$ peptides V3$\mathrm{W}$ and V3-W5 were similarly apt to distinguish B from $\mathrm{B}^{\prime \prime}$ plasma, with a slightly better performance of the V3-W5 peptide.

\section{Discussion}

The results presented in this study confirm and extend previous reports (Vanderborght et al., 1991, 1992; Bongertz et al., 1994; Cheingsong Popov et al., 1994; Pau et al., 1994; Pinto and Schechter, 1995; Hendry et al., 1996) on specificity of antibody binding to subtype-specific synthetic V3 peptides in that (a) reactivity of Brazilian HIV seropositive plasma with subtype B synthetic peptides is quite high (b) the $\mathrm{B}^{\prime \prime}$ variant of the $\mathrm{B}$ subtype, apparently characteristic of South American HIV-1 strains, can be distinguished from classical B subtype strains by antibody binding assays in the majority of cases and (c) differentiation of B and F subtypes cannot be accomplished by these serotyping assays. The number of $\mathrm{D}$ $(n=1)$ plasma available for this study precludes evaluation. The immunodominant gp41 peptide (amino acids 594-613) was recognized by $85 \%$ of all plasma tested, lower than found in North American studies (Gnann et al., 1987) but similar to Brazilian reactivity results described before (Bongertz and Morgado, 1994).

One of the unexpected results observed is the higher reactivity of plasma from male individuals in comparison to that observed for plasma from 
Table 4

Recognition of synthetic peptides (number of positive plasma/number of plasma tested) by plasma from patients grouped for exposure category and disease progression according to clinical staging ${ }^{\text {a }}$

\begin{tabular}{lllllrr}
\hline & Symptomatic IDU & Symptomatic MSM & $P$ & Symptomatic IDU & Symptomatic He & $P$ \\
\hline V2MN & $17 / 26$ & $3 / 15$ & 0.0088 & $17 / 26$ & $4 / 40$ & 0.0000 \\
V2BR & $14 / 20$ & $5 / 15$ & 0.0442 & $14 / 20$ & $9 / 41$ & 0.0005 \\
735 & $17 / 24$ & $3 / 15$ & 0.0031 & $17 / 24$ & 0.0000 & 0.0005 \\
FBR & $21 / 26$ & $8 / 15$ & 0.08 & $21 / 26$ & $15 / 41$ & \\
\hline
\end{tabular}

a IDU, injecting drug users, MSM, men who have sex with men, heterosexual transmission.

female patients. As no direct explanation for this observation is available, we hypothesized that more advanced disease progression, the age of the patients or, possibly, a restriction of HIV-1 subtypes/variants among different exposure categories could be contributing factor. This higher reactivity observed in plasma from male HIV-1 infected individuals is probably not related to a more advanced disease progression, as $68 \%$ of the male patients and $65 \%$ of the female ones were asymptomatic at sample collection. Group partition based on CD4 lymphocyte numbers showed similarly significant associations. However, it must be remembered that significant gender differences exist between exposure categories. When gender-related peptide recognition was associated to blood vs. sexual HIV transmission, males infected by blood transmission had a higher frequency of peptide recognition than those infected by sexual transmission. Multiple logistic regression procedure confirmed the high importance of route of HIV-1 transmission in frequency of peptide recognition, mainly for peptides gp41-735 and V2, V3-FBR and V3-D which were more frequently recognized by plasma from individuals infected by blood compared to those infected by sexual routes. Disease progression was less relevant, although significant for all tested peptides. On the other hand, gender did not show relevant effects in the multivariate analyses.

Although the extent of disease progression appeared to be slightly less for the groups of sexually infected patients than for the group infected through HIV-1 infected blood, both in terms of clinical classification and number of circulating CD4 lymphocytes at sample collection, and therefore the IDU group of patients could be consid- ered as 'more advanced in disease', the more frequent reactivity was shown by multiple logistic statistical analyses to be more closely associated with exposure category than with disease progression as assessed by numbers of CD4 lymphocytes.

The generally observed immunological abnormalities in IDUs may include a fast response by an already activated immune system (Wetli et al., 1974). The higher anti-V3 immune response observed in IDUs could possibly be correlated to the slower evolution rate of HIV-1 (= better immune control of evolution) in these patients, where the virus immediately encounters optimal conditions for replication. However, the higher antibody reactivity of MSM in comparison to heterosexuals could not be explained by these considerations, as this last group is generally considered as a group with a 'more restrictive bottleneck' difficulting HIV-1 adaptation (Lukashov and Goudsmit, 1997). We consider it therefore possible that the more numerous exposures to infection usually suffered by MSM or by IDUs in comparison to the heterosexually infected individuals (which did not include professional female sex workers) could be of higher importance in stimulation of a specific immune response [not necessarily protective (Schreiber et al., 1994)] than recognized up to now.

The data of this study indicate that patients with more advanced disease show a higher reactivity with the peptides studied than did asymptomatic patients, independent of anti-retroviral therapy.

However, the overall higher reactivity of HIV-1 F subtype plasma was apparently not derived from a more advanced disease progression of these patients, as a similar proportion of each 
Table 5

Adjusted odds ratios (OR) for route of HIV-1 transmission, disease progression and gender, multiple logistic regression results of peptide recognition

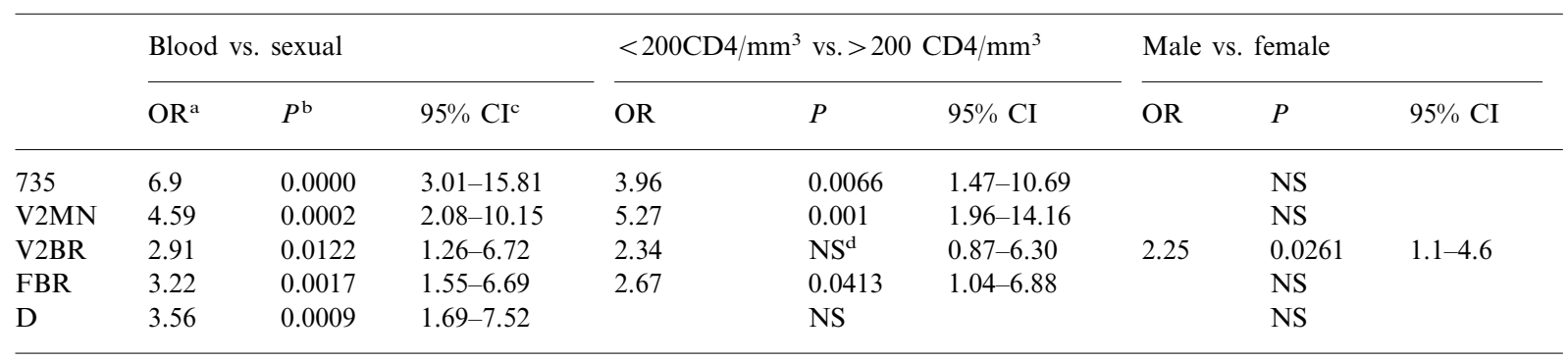

a Odds ratio.

${ }^{\text {b }} P$ value.

c $95 \%$ confidence interval.

d Not significant.

HIV-1 subtype/variant ( $\approx 70 \%: 48 / 72 \quad \mathrm{~B} ; 33 / 47$ $\mathrm{B}^{\prime \prime}$; and 10/18 F) was detected in asymptomatic patients.

The higher reactivity of plasma from symptomatic patients appears to be more frequent against the homologous V3 peptides, within the HIV-1 subtype (such as $B$ and $\mathrm{B}^{\prime \prime}$ ) and with the peptides known to be recognized by cross-reactive antibodies, as is the case of the HIV-1 B and F subtypes, most significantly the Brazilian peptides FBR and W5. This 'intensification' of homologous peptide recognition is probably explained by the increase in variability within the HIV-1 subtype ('quasispecies' development?), related to period of infection, exposing increasing

Table 6

Recognition of synthetic peptides (number of positive plasma/ number of plasma tested) by plasma from individuals grouped according to the genetic subtype/variant of HIV-1 harboured

\begin{tabular}{lllr}
\hline & B & B & \multicolumn{1}{l}{ F } \\
\hline ID & $56 / 74(75.7 \%)$ & $40 / 46(86.9 \%)$ & $18 / 20(90.0 \%)$ \\
V2MN & $21 / 74(28.3 \%)$ & $13 / 49(26.5 \%)$ & $10 / 18(55.6 \%)$ \\
V2BR & $22 / 70(31.4 \%)$ & $18 / 48(37.5 \%)$ & $8 / 18(44.4 \%)$ \\
735 & $18 / 71(25.3 \%)$ & $10 / 47(21.3 \%)$ & $8 / 19(42.1 \%)$ \\
B & $56 / 75(74.7 \%)$ & $18 / 48(37.5 \%)$ & $18 / 20(90.0 \%)$ \\
W & $44 / 75(58.7 \%)$ & $42 / 47(89.4 \%)$ & $13 / 19(68.4 \%)$ \\
W5 & $42 / 76(55.3 \%)$ & $37 / 46(80.4 \%)$ & $15 / 20(75.0 \%)$ \\
FBR & $32 / 76(42.1 \%)$ & $12 / 47(25.5 \%)$ & $14 / 19(73.7 \%)$ \\
F & $59 / 76(77.6 \%)$ & $27 / 48(56.3 \%)$ & $18 / 20(90.0 \%)$ \\
C & $35 / 75(46.7 \%)$ & $14 / 49(28.6 \%)$ & $11 / 20(55.0 \%)$ \\
D & $32 / 73(43.8 \%)$ & $13 / 48(27.1 \%)$ & $10 / 20(50.0 \%)$ \\
\hline
\end{tabular}

numbers of variants to the immune response of the individuals. Whether a higher specific immune response is of importance in inducing new variants, and up to when the new variants can induce a response in an increasingly deficient immune system will probably vary for individual patient/ virus combinations.

An analysis of the results presented as to their usefulness in serotyping indicates that the V3 peptide binding assay is not able to distinguish the two HIV-1 subtypes B and F, while capable of identification of the majority of $\mathrm{B}^{\prime \prime}$ variant HIV-1 infections. The FBR peptide appears to be more useful for identification of $\mathrm{F}$ plasma as crossrecognition by $\mathrm{B}$ and $\mathrm{B}^{\prime \prime}$ plasma is lower than observed for the F peptide. The B" peptides V3-W and V3-W5 were similarly apt to distinguish $B$ from $\mathrm{B}^{\prime \prime}$ plasma, with a slightly better performance of the V3-W5 peptide (not containing the Methionine adjacent to the GWGR top of the V3 loop).

More studies are needed to establish if the identification of the B" HIV-1 variant is important in anti HIV-1 therapy or choice of anti-HIV1 vaccines. Data available up to now indicate that in regard to viral neutralization the $\mathrm{B}^{\prime \prime}$ variant of the HIV-1 B subtype shows similar susceptibility to neutralizing antibodies (Bongertz et al., 1998b), even though differences in antibody binding assays are observed (Cheingsong Popov et al., 1994; Pau et al., 1994; Bongertz et al., 1998a). 
As to the extensive cross-reactivity observed between genotypically distinct HIV-1 subtypes, apart from the similarity of the V3 peptides used, a possible explanation could be in vivo variations of $\mathrm{V} 1 / \mathrm{V} 2$ sequences affecting response to a given V3 sequence (Rencher and Hurwitz, 1997) and number and position of glycosylation sites (Groenink et al., 1993; Back et al., 1994) which would reflect in in vitro differences of response against synthetic peptides, thereby diminishing the usefulness of serotyping assays. Little is known about the variability of the V1/ V2 region or other immunologically relevant epitopes in the envelope of primary HIV-1 isolates circulating in Brazil. The results shown here indicate that recognition of V2 peptides and of the gp41 735-752 epitope is similar for antibodies from B and $\mathrm{B}^{\prime \prime}$ infected individuals, indicating that the characteristic amino-acid sequence differences observed in the V3 loop may not be accompanied by differences in V2 or gp41-735 sequences. However, recognition of these peptides was generally very low (with exception of plasma from the IDU group). The higher recognition of these peptides by plasma from individuals infected with $F$ subtype HIV-1 may indicate a greater homogeneity of these epitopes in HIV-1 F subtype isolates.

In conclusion, the data reported indicate that important differences in the humoral immune response against HIV-1 can be observed in different HIV-1 transmission routes, with a more frequent reactivity observed in individuals infected by HIV-1 positive blood than observed for individuals infected by sexual exposure to HIV-1. The frequency of peptide recognition was higher for individuals in more advanced stages of the infection. $\mathrm{B}$ and $\mathrm{F}$ subtypes of HIV-1 cannot be distinguished by a simple V3peptide binding assay, while a variant of the $B$ subtype, the $\mathrm{B}^{\prime \prime}$ variant, can be identified in the majority of cases $(\approx 80 \%)$. Whether this extreme cross-reactivity between $\mathrm{B}$ and $\mathrm{F}$ plasma recognition of $\mathrm{V} 3$ peptides is indicative of a similarity in effective anti-HIV-1 immune response remains to be resolved.

\section{Acknowledgements}

Research supported by the FIOCRUZ Integrated AIDS Program PIAF, World Bank 063/ 94, CNPq 520922/95-6 and $\mathrm{CNPq} / \mathrm{MRC}$ (Canada).

\section{References}

Back NKJ, Shmit L, de Jong J, Keulen W, Schutten M, Goudsmit J, Tersmette M. An N-glycan within the HIV-1 gp120 V3 loop affects virus neutralization. Virology 1994; 199:431-8.

Bongertz V, Morgado MG. Prevalence of antibodies against an immunodominant region of the HIV-1 envelope glycoprotein gp41 in plasma from HIV-1 infected individuals in Brazil. Mem Inst Oswaldo Cruz 1994;89:369-70.

Bongertz V, Jansson M, Flodby P, Morgado MG, GalvãoCastro B, Wigzell H. Analysis of antibody specificity against the third variable region of the envelope gp120 of HIV-1 in plasma from HIV-1 positive individuals resident in Brazil. Braz J Med Biol Res 1994;27:1225-36.

Bongertz V, Costa CI, Guimarães ML, Soares-da-Costa MFG, Grinsztejn B, The HEC/FIOCRUZ AIDS Clinical Research Group, Bastos FI, Pilotto JH, João Filho EC, Loureiro R, Chequer P, Telles PR, Galvão-Castro B, Morgado MG. HIV specific humoral immune response in Rio de Janeiro, Brazil. Mem Inst Oswaldo Cruz 1998a;93:391-398.

Bongertz V, Costa CI, Guimarães ML, Grinsztejn B, The HEC/FIOCRUZ AIDS Clinical Research Group, João Filho EC, Galvão-Castro B, Morgado MG. Neutralization susceptibility of B subtype variant B" primary HIV-1 isolates. Scand J Immunol 1998b;47:603-608.

Casseb J, Hong MA, Gonsalez C, Duarte AJS, Hendry RM. HIV-1 serotyping among a cohort of individuals from São Paulo City, Brazil. Segundo Simpósio Brasileiro de Pesquisa Básica em HIV/AIDS, Angra dos Reis, RJ Abstract 1997:14.

Centers For Disease Control. Classification system for human T-lymphotropic virus type III/lymphoadenopathy associated virus infections. Ann Int Med 1986;105:234-237.

Cheingsong Popov R, Lister S, Callow D, Kaleebu P, Beddows S, Weber J, The WHO Network for HIV Isolation and Characterization. Serotyping HIV type 1 by antibody binding to the V3 loop: relationship to viral genotype. AIDS Res Human Retroviruses 1994;10:1379-1386.

Delwart EL, Shpaer EG, Louwagie J, Mc Cutchan FE, Grez M, Ruebsamen-Waigmann H, Mullins J. Genetic relationships determined by a DNA heteroduplex motility assay: analysis of HIV-1 env genes. Science 1993;262:1257-61.

Expert Group of the Joint United Nations Programme on HIV/AIDS. Implications of HIV variability for transmission: scientific and policy issues. AIDS 11 UNAIDS1-UNAIDS15, 1997. 
Galvão-Castro B, Couto-Fernandez JC, Mello MA, Linhares de Carvalho MI, Castello Branco LR, Bongertz V, Ferreira PC, Morgado MG, Tanuri A, Sabino E, The Brazilian Network for HIV-1 Isolation and Characterization. A nationwide effort to systematically monitor HIV-1 diversity in Brazil: preliminary results. Mem Inst Oswaldo Cruz 1996;91:335-338.

Gao F, Morrison SG, Robertson DL, Thornton CL, Craig S, Karlsson G, Sodroski J, Morgado M, Galvão-Castro G, von Briesen $\mathrm{H}$, Beddows S, Weber J, Sharp PM, Shaw GM, Hahn BH, The WHO and NIAID Networks for HIV Isolation and Characterization. Molecular cloning and analysis of functional envelope genes from Human Immunodeficiency Virue Type 1 sequence subtypes A through G. J Virol 1996;70:1651-67.

Gnann JW, Schwimmbeck PL, Nelson JA, Traux AB, Oldstone MBA. Diagnosis of AIDS by using a 12 amino acid peptide representing an immunodominant epitope of HIV. J Inf Dis 1987;156:261-7.

Groenink M, Fouchier RA, Broersen S, Baker CH, Koot M, Van't Wout AB, Huisman HG, Miedema F, Tersmette M, Schuitemaker H. Relation of phenotype evolution of HIV1 to envelope V2 configuration. Science 1993;260:1513-6.

Hendry RM, Hanson CV, Bongertz V, et al. Immunoreactivity of Brazilian HIV isolates with different V3 motifs. Mem Inst Oswaldo Cruz 1996;91:347-8.

Hendry RM. HIV-1 serotyping: application to global populations identification of a South American subtype B variant, and role in vertical transmission. Segundo Simpósio Brasileiro de Pesquisa Básica em HIV/AIDS, Angra dos Reis, RJ, 1997.

Lukashov VV, Goudsmit J. Founder virus population related to route of virus transmission: a determinant of intrahost HIV type 1 evolution? J Virol 1997;71:2023-30.

Morgado MG, Sabino EC, Shpaer EG, et al. V3 region polymorphism in HIV-1 from Brazil: prevalence of subtype B strains divergent from the North American/European prototype and detection of subtypes F. Aids Res Human Retroviruses 1994;10:569-75.

Morgado MG, Guimarães ML, Gripp CBG, Costa CI, Neves I Jr, Veloso VG, Linhares de Carvalho MI, CastelloBranco LR, Bastos FI, Kuiken C, Castilho EA, GalvãoCastro B, Bongertz V, The HEC AIDS Clin Res Group. Molecular epidemiology of HIV in Brazil: high prevalence of B subtype and identification of a HIV-1 subtype D infection in Rio de Janeiro City. J AIDS Human Retrovirol 1998;18:488-194.
Pau CP, Kai M, Holloman-Candal DL, Luo CC, Kalish ML, Schochetman G, Byers B, George JR, The WHO Network for HIV isolation and characterization. Antigenic variation and serotyping of HIV type 1 from four World Health Organization-sponsored vaccine sites. AIDS Res Human Retroviruses 1994;10:1369-77

Pinto ME, Schechter M. V3 peptide pattern and HIV-1 transmission route in Rio de Janeiro. Mem Inst Oswaldo Cruz 1995;90:683-5.

Potts KE, Kalish ML, Lott T, et al. The Brazilian Collaborative AIDS Research Group. Genetic heterogeneity of the V3 region of the HIV-1 envelope glycoprotein in Brazil. AIDS 1993;7:1191-7.

Rencher SD, Hurwitz JL. Effect of natural HIV-1 envelope V1-V2 sequence diversity on the binding of V3-specific and non-V3-specific antibodies. J AIDS 1997;16:69-73.

Sabino E, Shpaer E, Morgado MG, et al. Identification of an HIV-1 proviral genome recombinant between subtype B and $\mathrm{F}$ in PBMCs obtained from an individual in Brazil. J Virol 1994;68:6340-6.

Schreiber M, Petersen H, Wachsmuth C, Müller H, Huber FT, Schmitz H. Antibodies of symptomatic HIV-1 infected individuals are directed to the V3 domain of non-infectious and not of infectious virions present in autologous serum. J Virol 1994;68:3908-16.

Vanderborght B, Deleys RJ, Morais de Sá CA, Santos EA, Cassalta RM, Alcantara VG, Sion FS, Bonecini MG, Von Heuverswyn, H. Anti-V3 loop reactivity in HIV-1 infected patients in Rio de Janeiro, Brazil. In: Eight International Conference on AIDS, Amsterdam, PoA 1992:2164

Vanderborght B, Santos EA, Alcantara VD, Cassalta RM, Bonecini MG, Sion FS, Morais-de-Sá, CA, Differences in V3 reactivities among HIV-1 infected patients; correlation with HIV-2 crossreactivity. In: First CEC-FIOCRUZ Joint Meeting, Angra dos Reis, RJ 1991.

Watkins BA, Reitz MS, Wilson CA, Aldrich A, Davis AE, Robert-Guroff M. Immune escape by human immunodeficiency virus type 1 from neutralizing antibodies. J Virol 1993;67:7493-500.

Wetli CV, Noto TA, Carol AF. Immunologic abnormalities in heroin addiction. South Med J 1974;67:193-7.

WHO Network for HIV Isolation and Characterization. HIV Type 1 variation in World Health Organization-sponsored vaccine evaluation sites: genetic screening, sequence analysis, and preliminary biological characterization of seleced viral strains. AIDS Res Human Retroviruses 1994; 10:1327-1343. 